\title{
The relationship between shooting performance and respiratory muscle strength in archers aged 9-12
}

Authors' Contribution: A Study Design B Data Collection C Statistical Analysis D Data Interpretation E Manuscript Preparation F Literature Search G Funds Collection
Özgür Bostanci ABCDEF, Menderes Kabadayi ABCDEF, Muhammet Hakan Mayda ABCDEF, Ali Kerim Yilmaz ABCDEF, Coşkun Yilmaz ABCDEF

Yaşar Doğu Faculty of Sports Sciences, Ondokuz Mayıs University, Samsun, Turkey

\section{abstract}

Background: The aim of this study is to investigate the relationship between shooting performance and pulmonary functions and respiratory muscle strength in archers.

Material and methods:

The research was conducted with 31 boy and 11 girl archers aged 9-12. The forced vital capacity (FVC), forced expiration volume in one second (FEV1), FEV1/FVC, peak expiratory flow (PEF), maximum voluntary ventilation (MVV), maximum inspiratory pressure (MIP), and maximum expiratory pressure (MEP) of the archers were measured. To determine the shooting performance, a total of 30 shots $(15+15)$ were taken from an 18-meter distance in closed shooting range.

Results: A significant difference was found between the 15 shots done in each half and the total shot point and the averages of FVC $(r=0.375,0.353,0.378$ respectively) and FEV1 ( $r=0.368,0.339,0.367$ respectively). However, a significant difference was not found among these shot points and other respiratory parameters $(p>0.05)$. A relationship was detected between the second 15-shot points of boy archers and $\operatorname{MEP}(r=0.370)$.

Conclusions: A strong correlation was not found between the respiratory parameters and shooting performances of the archers in this study. However, it is thought that this level of relationship will rise as training level and age increases.

Key words: archery, respiratory function, respiratory muscle strength, shooting performance.

\section{article details}

Article statistics: Word count: 2,045; Tables: 3; Figures: 0; References: 28

Received: July 2020; Accepted: May 2021; Published: September 2021

Full-text PDF: http://www.balticsportscience.com

Copyright @ Gdansk University of Physical Education and Sport, Poland

Indexation: Celdes, Clarivate Analytics Emerging Sources Citation Index (ESCI), CNKI Scholar (China National Knowledge Infrastructure), CNPIEC, DOAJ, EBSCO - Central \& Eastern European Academic Source, EBSCO - SPORTDiscus, EBSCO Discovery Service, Google Scholar, Index Copernicus, J-Gate, Naviga (Softweco, Primo Central (ExLibris), ProQuest - Family Health, ProQuest - Health \& Medical Complete, ProQuest - Illustrata: Health Sciences, ProQuest Nursing \& Allied Health Source, Summon (Serials Solutions/ProQuest, TDOne (TDNet), Ulrich's Periodicals Directory/ ulrichsweb, WorldCat (OCLC)

Funding: This research received no specific grant from any funding agency in the public, commercial, or not-for-profit sectors.

Conflict of interests: Corresponding author:

Open Access License:
Authors have declared that no competing interest exists.

Muhammet Hakan MAYDA, Ondokuz Mayıs University, Yaşar Doğu Sport Science Faculty, Samsun, Turkey; Yaşar Doğu Sport Science Faculty, 55100, Samsun, Turkey; Phone Number: +90 505593 1827; E-mail: hakan.mayda@omu.edu.tr

This is an open access article distributed under the terms of the Creative Commons Attribution-Non-Commercial-NoDerivatives 4.0 International (https://creativecommons.org/licenses/by-nc-nd/4.0/), which permits use, distribution, and reproduction in any medium, provided the original work is properly cited, the use is non-commercial and is otherwise in compliance with the license. 


\section{INTRODUCTION}

Archery is one of the oldest sports in history and is still among popular sports [1]. Like in other sports, there are some psychometric and physiological features that come into prominence [2], because in order to get a good score in an archery competition, one needs to have a high level of body control, skill and focus as well as the ability of synchronizing and repeating the stages of posture, holding the bow, pulling, aiming the shot and continuing to shoot $[3,4]$. Although this seems like a basic process, it is affected by factors such as reaction time, focus on the aim, sufficient coordination, technical features, breathing control, and psychological state [5, 6].

The most important physiological mechanism in archery is the heart rate and shooting moment [7]. As the heart rate increases, the diastolic phase of the cardiac cycle shortens, while the systolic phase extends. A small movement that occurs in the systolic phase of the cardiac cycle causes problem in shooting sports [8]. For this reason, high-performance archers usually control their heart rate while shooting and shoot with a low heart rate. For a controlled heart rate, good respiratory capacity is necessary because the heart rate range decreases when respiratory frequency is controlled [9].

Breathing is an action that affects the diaphragm, ribcage, abdominal cavity and shoulders. Moving the shoulders makes it impossible to focus on a fixed target. For an effective shooting technique, an athlete should not breathe and shoot the arrow at the same time. Breathing is an action that is important throughout the entire process of shooting. An incorrectly applied breathing technique will cause the need to breathe in again, and this will cause less control and losing concentration which will lead to losing points [10]. In order to breathe effectively, it is important to have a healthy respiratory system [11]. The respiratory system, its functions and respiratory muscle strength are highly significant for archery, and with recent technology, it has become possible to measure these, which has led to many scientific studies [12,13]. Improving respiratory muscle strength helps fix the relationship between respiratory muscle length and tension, and it helps increase respiratory capacity. We hypothesize that there will be a relationship between shooting performance and respiratory functions in archers.

\section{MATERIAL AND METHODS}

\section{PARTICIPANTS}

Forty-two classic archers participated in this study; 11 girls $(10.09 \pm 1.14)$ and 31 boys (10.45 \pm 0.99$)$. The archers were aged 9-12 years old and they had participated in competitions as licensed athletes for at least 1 year. Descriptive data regarding the participants' characteristics are presented in Table 1 below.

Table 1. Descriptive data (Mean \pm SD)

\begin{tabular}{cccc}
\hline Variables & Boys $(\mathrm{n}: 31)$ & Girls $(\mathrm{n}: 11)$ & Total $(\mathrm{n}: 42)$ \\
\hline Age (years) & $10.45 \pm 0.99$ & $10.09 \pm 1.14$ & $10.36 \pm 1.03$ \\
Height $(\mathrm{cm})$ & $147.13 \pm 7.08$ & $144.73 \pm 10.39$ & $146.50 \pm 8.01$ \\
Weight $(\mathrm{kg})$ & $41.45 \pm 9.66$ & $36.36 \pm 8.66$ & $40.12 \pm 9.57$ \\
BMI $\left(\mathrm{kg} / \mathrm{m}^{2}\right)$ & $18.97 \pm 3.26$ & $17.23 \pm 2.70$ & $18.52 \pm 3.18$ \\
Sports experience (years) & $2.23 \pm 0.43$ & $2.36 \pm 0.50$ & $2.26 \pm 0.45$ \\
\hline
\end{tabular}

$\mathrm{n}=$ Sample size, $\mathrm{SD}=$ Standard deviation, $\mathrm{BMI}=$ Body mass index

Athletes who had an injury record or suffered from a serious injury were not included in this study. In order to help the participants adapt to the measurement process, they were 
informed about the tests, and a pilot study was done 1 week before measurements. The study was carried out at Samsung Kuzey Archery in 2019. All procedures were approved by the Clinical Research Ethics Committee of Ondokuz Mayıs University, and the whole process was conducted according to the standards of the Helsinki Declaration. Written informed consent was obtained from each subject.

\section{Pulmonary Function Tests}

Pulmonary function measurements were performed using a spirometer (CPFS/D USB Spirometer, MGC Diagnostics, Saint Paul, MN, USA). Forced vital capacity (FVC), forced expiration volume in one second (FEV1), the FEV1/FVC ratio, maximal peak expiratory flow (PEF max) and maximal voluntary ventilation (MVV) were recorded using this pulmonary function test. The best measurements for each subject were used in the subsequent analyses [14].

\section{Respiratory Muscle Strength}

MIP (maximal inspiratory pressure) and MEP (maximal expiratory pressure) were measured with a portable hand held mouth respiratory pressure meter (MicroRPM, CareFusion Micro Medical, Kent, UK). After the proper filters and holders were fixed, the nasal airway was closed with a clip. The MIP measurement started with the residual volume, and MEP assessment began with total lung capacity. Measurements were performed three times, and the best value was recorded [14].

\section{Shooting Performance}

One week after the respiratory function tests we conducted, athletes aged 9-12 did a total of 30 shots $(15+15)$ from an 18-meter distance in a closed shooting range. After completing the first 15 shots, the athletes had a 15-minute rest before the other 15 shots. The total points of the 30 shots were considered as the archery success performance data. Each shot was assessed between 0-10 points. Each athlete got scores between 0 and 300 after their shots. The scores obtained by the athletes and the respiratory values measured a week before were examined.

\section{Statistical Analysis}

Data obtained from the study were analyzed by using the SPSS (SPSS for Windows, version 22.0, 2008, SPSS Inc., Chicago, Illinois, USA) package program. The data was presented as mean, standard deviation, and effect size (Cohen's d). The Shapiro-Wilk test was used to assess normality. To determine the relationship between the shooting points of the participants and their pulmonary functions and muscle strength, the Pearson correlation test was used. To detect the difference between genders, the independent t-test was applied. The statistical results were evaluated according to the significance level of $\mathrm{p}<0.05$.

\section{RESULTS}

Data obtained from the research was presented with their mean values and statistical results. No difference was found when respiratory functions and shooting performance were compared based on gender $(\mathrm{p}>0.05)$. However, it was discovered that the shooting scores of girl athletes $(242.00 \pm 30.52)$ were higher than those of boy athletes $(221.71 \pm 56.42)(p>0.05)$ (Table 2).

When the relationship between respiratory functions and the total 18-meter shooting performance is examined, there is a significant relationship in terms of FVC $(r=0.378)$ and FEV1 $(r=0.367)(p<0.05)$. However, no relationship was found between the other parameters ( $p>0.05)$. A significant relationship was found between the total 30 shot points and FVC values of girl athletes $(r=0.631)$ and also between the second 15 shots and MEP averages of boy athletes $(r=0.370)(p<0.05)$ (Table 3$)$. 
Table 2. Comparison of variables based on gender

\begin{tabular}{|c|c|c|c|c|}
\hline \multirow{2}{*}{ Variables } & \multicolumn{2}{|c|}{ Mean \pm SD } & \multirow{2}{*}{ Cohen's d } & \multirow{2}{*}{$\mathrm{p}$} \\
\hline & Boys $(n=31)$ & Girls $(n=11)$ & & \\
\hline FVC (It) & $2.22 \pm 0.36$ & $2.13 \pm 0.44$ & 0.22 & 0.537 \\
\hline FEV1 (It) & $2.07 \pm 0.33$ & $2.07 \pm 0.44$ & - & 0.923 \\
\hline FEV1/FVC (\%) & $93.90 \pm 5.75$ & $96.73 \pm 3.74$ & -0.58 & 0.138 \\
\hline PEF (It/sec) & $307.32 \pm 43.92$ & $304.91 \pm 44.81$ & 0.05 & 0.877 \\
\hline MVV (It/min) & $76.03 \pm 15.75$ & $72.82 \pm 11.86$ & 0.23 & 0.542 \\
\hline $\mathrm{MIP}(\mathrm{cmH} 2 \mathrm{O})$ & $76.94 \pm 25.00$ & $75.36 \pm 25.33$ & 0.06 & 0.859 \\
\hline MEP $(\mathrm{cmH} 2 \mathrm{O})$ & $96.97 \pm 25.66$ & $85.00 \pm 15.80$ & 0.56 & 0.156 \\
\hline First 15-shot points & $110.29 \pm 30.58$ & $117.27 \pm 17.67$ & -0.28 & 0.480 \\
\hline Second 15-shot points & $111.42 \pm 27.84$ & $124.73 \pm 14.14$ & -0.60 & 0.139 \\
\hline Total 30-shot points & $221.71 \pm 56.42$ & $242.00 \pm 30.52$ & -0.45 & 0.265 \\
\hline
\end{tabular}

$\mathrm{SD}=$ Standard deviation, FVC $=$ Forced vital capacity, FEV1 = Forced expiratory volume in one second, PEF = Peak expiratory flow, $\mathrm{MVV}=$ Maximal voluntary ventilation, MIP = Maximal inspiratory pressure, MEP = Maximal expiratory pressure, Cohen's d = effect size

Table 3. Analysis of the relationship between shooting scores and respiratory functions

\begin{tabular}{ccccccccc}
\hline Varaiables & & FVC & FEV1 & FEV1/FVC & PEF & MVV & MIP & MEP \\
\hline \multirow{2}{*}{$\begin{array}{c}\text { First 15-shot } \\
\text { points }\end{array}$} & Boys & 0.347 & 0.341 & -0.023 & 0.053 & 0.041 & 0.003 & 0.277 \\
& Girls & $0.668^{*}$ & 0.595 & -0.280 & 0.160 & 0.420 & 0.289 & 0.238 \\
& Total & $0.375^{*}$ & $0.368^{*}$ & -0.024 & 0.066 & 0.077 & 0.045 & 0.239 \\
\hline \multirow{2}{*}{$\begin{array}{c}\text { Second 15-shot } \\
\text { points }\end{array}$} & Boys & $0.385^{*}$ & 0.352 & -0.111 & 0.153 & 0.215 & 0.078 & $0.370^{*}$ \\
& Girls & 0.528 & 0.479 & -0.173 & 0.159 & 0.212 & 0.086 & 0.011 \\
\hline \multirow{2}{*}{$\begin{array}{c}\text { Total 30-shot } \\
\text { points }\end{array}$} & Total & $0.353^{*}$ & $0.339 *$ & -0.057 & 0.140 & 0.183 & 0.068 & 0.267 \\
\hline & Goys & $0.378^{*}$ & $0.359 *$ & -0.067 & 0.105 & 0.128 & 0.040 & 0.333 \\
& Girls & $0.631^{*}$ & 0.566 & -0.242 & 0.166 & 0.341 & 0.207 & 0.143 \\
\hline potal & $0.378^{*}$ & $0.367 *$ & -0.041 & 0.105 & 0.133 & 0.058 & 0.262 \\
\hline
\end{tabular}

$* \mathrm{p}<0.05, \mathrm{FVC}=$ Forced vital capacity, FEV1 $=$ Forced expiratory volume in one second, PEF = Peak expiratory flow, $\mathrm{MVV}=$ Maximal voluntary ventilation, MIP = Maximal inspiratory pressure, MEP = Maximal expiratory pressure

\section{DISCUSSION}

The aim of this study was to investigate the relationship between shooting performance and respiratory functions in archers. The regular practice of a sports activity helps not only with physical and physiological improvement, but also with respiratory functions [15]. Beside psychomotor features, respiratory functions are highly significant for archers because breathing is a factor that affects success while shooting [9].

In this study, pulmonary functions and respiratory muscle strength were compared with an 18-meter shooting performance to examine the relationship between the two, and a positively significant relationship was found between FVC, FEV1 parameters and shooting scores $(p<0.05)$ (Table 3). Research has shown that descriptive factors of children such as age, height and weight affect their pulmonary functions and respiratory muscle strength. Studies have also found that there is a positively significant relationship between age and respiratory functions in the 8-12-year-old age group [16]. Although the relationship between age and these parameters is known, it is also indicated that height, weight and physical activity levels lead to differences in respiratory functions, especially in respiratory muscle strength $[17,18]$. Besides this, there is also a high correlation between respiratory muscle strength and pulmonary functions [19].

In archery, upper limbs and the strength and endurance of the upper body is directly linked to performance [20]. It has been proven that training does not cause stress in the respiratory 
system of archers [21]. It has also been found that the lung volume in archers is higher compared to others [22]. This is because lung volume is very effective on the heart rate and affects performance. It is known that higher heart rate values show low correlation with scoring points [7]. A large number of studies on archers have examined the relationship between the heart rate during the shooting period and performance and found a decrease in the heart rate while shooting $[23,24]$. Also in archery, the strength and durability of core muscles are directly associated with better performance [20]. The diaphragm, which is one of the leading core muscles, is the most important muscle of the respiratory system [25]. This physiological mechanism shows that there is an association between successful shot, cardiac cycle and respiratory functions in archery.

McArdle et al. [21] have also found that breathing, the heart rate and the cardiovascular system of archers are higher. A successful shot in archery is done with controlled breathing and using respiratory functions effectively. Since training sessions include special breathing exercises, it can be said that this leads to differences when compared to other sport disciplines and respiratory parameters.

A significant difference was found when pulmonary functions, respiratory muscle strength and shooting performance were compared based on gender $(p>0.05)$. The result that there was no difference in these parameters based on the gender variable is due to the fact that development in both genders is similar. However, it is known that the values of boys become higher later on [26].

Baltacl et al. [27] examined the respiratory parameters of boys in different sport disciplines and found an increase in their MVV values after exercise. Another study found that the resting heart beat and blood pressure of elementary students in a school team were lower compared to students who participated in sport. It was also found that VC and FVC values were higher in those who participated in sport [28].

\section{LIMITATION}

The spirometer that was used did not calculate some other important pulmonary parameters, such as forced expiratory flow, peak expiratory flow, forced inspiratory flow, and peak inspiratory flow. In addition, the study was conducted on a small sample size.

\section{CONCLUSION}

As a conclusion, this study examined the relationship between performance and the active pulmonary functions and respiratory muscle strength, especially during the shooting process, of archers aged 9-12 years. It was found that there was a relationship between FVC, FEV1 and MEP. The fact that the participants in this study were from a very young age group and had a short training history has led to certain relationships in limited parameters. Beside their regular training, athletes need to practice specific exercises for their respiratory muscles and respiratory system (diaphragmatic breathing, respiratory muscle training, etc.) in order to improve shooting performance. Thus, the relationship between respiratory functions and shooting performance can increase. Also, trainers need to regularly monitor the respiratory values of these young athletes and study the relationship between these values and performance. It may be recommended that special breathing exercises are regularly included in the training of archers.

\section{REFERENCES}

[1] Öngel B. Early inner Asian Turkish archery in the development process. Gazi University Journal of Gazi Education Faculty. 2001;21:189-215. 
[2] Kılınç F, Cesur G, Atay E, Ersöz G, Kılıç T. Investigation of physical, physiological and force factors affecting the technical shoot performance of 10-14 age group elite women archer. SDU Med Faculty J. 2010;17(3):18-24.

[3] Şimşek D, Ertan H. Postural control and sport: postural sensor motor strategies and postural sway in different sport branches. Spormetre J Phys Educ Sport Sci. 2011;9(3):81-90. https://doi.org/10.1501/Sporm_0000000203

[4] Deeny SP, Hillman CH, Janelle MC, Hatfield BD. Cortico-cortical communication and superior performance in skilled marksmen: An EEG coherence analysis. J Sport Exerc Physiol. 2003;25:188-204. https://doi.org/10.1123/jsep.25.2.188

[5] Aksoy Y, Ağaoğlu SA. The comparıson of sprınt reactıon tıme and anaerobıc power of young football players, volleyball players and wrestlers. Kinesiol Slov. 2017;23(2):5-14.

[6] Axford R. Archery anatomy: An introduction to techniques for improved performance. Souvenir Press; 2017.

[7] Guru CS, Krishnan A, Mahajan U, Sharma D. Heart rate values during shooting is a field-side performance analysis tool in archery-a study of elite Indian archers. Int J Sport Stud Hlth. 2020;3(1):1-6. https://doi.org/10.5812/intjssh.99687

[8] Guyton AC, Hall JE. Guyton and Hall textbook of medical physiology e-Book. Elsevier Health Sciences; 2020.

[9] Mohamed MN, Norman WMNW, Linoby A, Sariman MH, Azam MZM. Breathing pattern influence to the shooting performance. In: Proceedings of the International Colloquium on Sports Science, Exercise, Engineering and Technology 2014; 321-333. Springer, Singapore.

[10] Santos MLDMD, Rosa BD, Ferreira CDR, Medeiros ADA, Batiston AP. Maximal respiratory pressures in healthy boys who practice swimming or indoor soccer and in healthy sedentary boys. Physiother Theor Pr. 2012;28(1):26-31. https://doi.org/10.3109/09593985.2011.560239

[11] Lomax ME, McConnell AK. Inspiratory muscle fatigue in swimmers after a single $200 \mathrm{~m}$ swim. J Sport Sci. 2003;21: 659-664. https://doi.org/10.1080/0264041031000101999.

[12] Volianitis S, McConnell AK, Koutedakis Y, McNaughton L, Backx K, Jones, DA. Inspiratory muscle training improves rowing performance. Med Sci Sport Exerc. 2001;33:803-809. https://doi.org/10.1097/00005768-200105000-00020

[13] Bartter TC, Pratter MR, Irwin RS. Respiratory failure Part I: A Physiologic Approach to Managing Respiratory Failure. In: Intensive Care Medicine, Ed. Irwin RS and Rippe JM. Philadelphia, Lippincott Williams \& Wilkins. 2003; 485-489.

[14] Bostanci Ö, Mayda H, Yllmaz C, Kabadayı M, Yılmaz AK, Özdal M. Inspiratory muscle training improves pulmonary functions and respiratory muscle strength in healthy male smokers. Respir Physiol Neuro. 2019;264:28-32. https:// doi.org/10.1016/j.resp.2019.04.001

[15] Bostanci Ö, Kabadayi M, Mayda MH, Yılmaz AK, Yılmaz Ç. The differential impact of several types of sports on pulmonary functions and respiratory muscle strength in boys aged 8-12. Isokinet Exerc Sci. 2019;27(4):307-312. https://doi.org/ 10.3233/IES-192105

[16] Choi WH, Shin MJ, Jang MH, et al. Maximal inspiratory pressure and maximal expiratory pressure in healthy Korean children. Ann Rehabil Med. 2017;41(2):299. https://doi.org/10.5535/arm.2017.41.2.299

[17] Arnall DA, Nelson AG, Owens B, et al. Maximal respiratory pressure reference values for Navajo children ages 6-14. Pediatr Pulmonol. 2013;48(8):804-808. https://doi.org/10.1002/ppul.22645

[18] Junior DC, Peixoto-Souza FS, Araujo PN, et al. Influence of body composition on lung function and respiratory muscle strength in children with obesity. J Clin Med Res. 2016;8(2):105-110. https://doi.org/10.14740/jocmr2382w

[19] Peterson-Carmichael S, Seddon PC, Cheifetz IM, et al. An official American Thoracic Society/European Respiratory [ Society workshop report: Evaluation of respiratory mechanics and function in the pediatric and neonatal intensive care units. Ann Am Thorac Soc. 2016;13(2):1-11. https://doi.org/10.1513/AnnalsATS.201511-730ST

[20] Humaid H. Influence of arm muscle strength, draw length and archery technique on archery achievement. Asian Soc Sci. 2014;10(5):28-34. https://doi.org/10.5539/ass.v10n5p28

[21] McArdle WD, Katch FI, Katch VL. Exercise Physiology: Nutrition, Energy, And Human Performance. Lippincott Williams \& Wilkins; 2010.

[22] Thakare V. Comparative study of peak expiratory flow rate of archery players participated in all India inter university archery competition. Int J Phys Educ Sports Health. 2015;2(2):331-332.

[23] Açıkada C, Hazır T, Asçı A, Aytar SH, Tınazcı C. Effect of heart rate on shooting performance in elite archers. Heliyon. 2019; 5(3): e01428. https://doi.org/10.1016/j.heliyon.2019.e01428

[24] Clemente F, Couceiro M, Rocha R, Mendes R. Study of the heart rate and accuracy performance of archers. J Phys Educ Sport. 2011;11(4):434-437

[25] Bostanci Ö, Kabadayi M, Yilmaz AK, Mayda MH, Yilmaz Ç, Erail S, Karaduman E. Influence of eight week core strength training on respiratory muscle strength in young soccer players. Int J Appl Exerc Physiol. 2020;9(6):221-226. https:// doi.org/10.26655/IJAEP.2020.6.1

[26] Siders WA, Lukaski HC, Bolonchuk WW. Relationships among swimming performance, body composition and somatotype in competitive collegiate swimmers. J Sports Med Phys Fitness. 1993;33:166-171.

[27] Baltacı AK, Moğulkoç R, Keleştimur H, Konar V, Kutlu S. Some respiratory parameters of different types of sports in boys and effect on MaxV02. Firat University Journal of Firat Medical. 1997;3:150-154.

[28] Alpay B, Altuğ K, Hazar S. Evaluation of some respiratory and cardiovascular parameters of sedentary compared with students attending elementary school teams in the 11-13 age. Mehmet Akif Ersoy University Journal of Education Faculty, 2008;8(17):22-29.

\section{Cite this article as:}

Bostanci O, Kabadayi M, Mayda MH, Yilmaz AK, Yilmaz C.

The relationship between shooting performance and respiratory muscle strength in archers aged 9-12

Balt J Health Phys Act. 2021;13(3):31-36

doi: 10.29359/BJHPA.13.3.04 